\title{
PENAFSIRAN KONSTITUSI DALAM BINGKAI HUKUM PANCASILA*
}

\author{
Andi Desmon \\ Fakultas Hukum Universitas Ekasakti Padang \\ Jl. Veteran Dalam No.26 B Padang, Sumatera Barat \\ e-mail: andidesmon21@gmail.com
}

\begin{abstract}
Interpretive activity is an inherent activity with law and legal science. However, during this study the science of law provides a limited place to the activities of interpretation. In fact, the science of law as a practical science in charge of guiding, directing, and controlling the practical application of rational law, should be able to offer alternative solutions to legal problems, so it should provide more space for interpretation activities. Through this research, the researcher described that the interpretation of the constitution within the scope of Pancasila law. This research was normative law research. The data used in this study comes from primary legal materials, secondary legal materials, and tertiary legal materials. The legal materials, collected through literature study, and analyzed qualitatively are then presented in the form of analytical descriptive. This study concludes that in order to realize a living constitution that is responsive to societal change, the interpretation of constitutional norms must be based on the meaning of the word and its sentence structure (grammatical), historical (historical), purpose (teleological) the other positive (systematic) laws of the law, and contextually referring to social and economic (sociological) factors with reference to fundamental (philosophical) cultural and humanitarian values (predictions) for future (futurological). The principles and content of Pancasila as a limitation or restriction in the interpretation of the constitution is a necessity for the future of Indonesia, as aspired in the Preamble to the 1945 Constitution.
\end{abstract}

Keywords: Constitution, Interpretation, Pancasila

\begin{abstract}
Abstrak
Kegiatan penafsiran merupakan aktivitas yang melekat dengan hukum dan ilmu hukum. Namun, selama ini studi ilmu hukum memberikan tempat yang terbatas terhadap kegiatan penafsiran. Padahal, ilmu hukum sebagai ilmu praktikal yang bertugas mempedomani, mengarahkan, dan mengontrol pengembanan hukum praktikal secara rasional, harus mampu menawarkan alternatif penyelesaian permasalahan hukum, sehingga sudah seharusnya memberikan ruang yang lebih terhadap kegiatan penafsiran. Melalui penelitian ini diuraikan mengenai penafsiran konstitusi dalam lingkup hukum Pancasila. Penelitian ini adalah penelitian hukum normatif. Data yang digunakan dalam penelitian ini bersumber dari bahan hukum primer, bahan hukum sekunder, dan bahan hukum tersier. Bahan-bahan hukum dimaksud, dikumpulkan melalui studi kepustakaan, dan dianalisis secara kualitatif yang kemudian disajikan dalam bentuk deskriptif analitis. Penelitian ini menyimpulkan bahwa untuk mewujudkan konstitusi yang hidup sehingga responsif terhadap perubahan masyarakat, maka penafsiran terhadap kaidah konstitusi harus berdasarkan pada makna kata dan struktur kalimatnya (gramatikal), latar belakang sejarah (historikal), tujuannya (teleologikal) serta dalam konteks hubungan dengan aturan-aturan hukum positif yang lainnya (sistematikal), dan secara kontekstual merujuk pada faktor-faktor kenyataan sosial dan ekonomi (sosiologikal) dengan mengacu nilai kultural dan kemanusiaan fundamental (filosofikal) serta prediksi untuk masa yang akan datang (futurologikal). Asas-asas dan kandungan nilai Pancasila sebagai batasan atau sandaran dalam melakukan penafsiran konstitusi merupakan keharusan untuk masa depan Indonesia, sebagaimana yang dicita-citakan dalam Pembukaan UUD 1945.
\end{abstract}

Kata kunci: Konstitusi, Penafsiran, Pancasila

* Naskah diterima: 08 Februari 2018, direvisi: 25 Februari 2018, disetujui untuk terbit: 06 Maret 2018 


\section{PENDAHULUAN}

Pembukaan Undang-Undang Dasar Negara Republik Indonesia Tahun 1945, ${ }^{1}$ menjiwai materi muatan UUD 1945. Materi muatan UUD 1945, mempercayakan penyelenggaraan negara kepada pengaturan (lebih lanjut) oleh undang-undang. ${ }^{2}$ Berkenaan dengan hal ini terlihat dengan jelas bahwa keberadaan undang-undang memiliki

1 Penyebutan resmi Undang-Undang Dasar Negara Republik Indonesia Tahun 1945, yang telah dilakukan empat kali perubahan, sebagaimana dimuat dalam Republik Indonesia, Perubahan Pertama Undang-Undang Dasar Negara Republik Indonesia Tahun 1945, Lembaran Negara Nomor 11, Lembaran Negara Tahun 2006; Republik Indonesia, Perubahan kedua Undang-Undang Dasar Negara Republik Indonesia Tahun 1945, Lembaran Negara Nomor 12, Lembaran Negara Tahun 2006; Republik Indonesia, Perubahan ketiga Undang-Undang Dasar Negara Republik Indonesia Tahun 1945, Lembaran Negara Nomor 13, Lembaran Negara Tahun 2006; Republik Indonesia, Perubahan keempat Undang-Undang Dasar Negara Republik Indonesia Tahun 1945, Lembaran Negara Nomor 14, Lembaran Negara Tahun 2006. Selanjutnya dalam penulisan ini ditulis UUD 1945.

${ }^{2}$ Dalam UUD 1945 hasil perubahan, terdapat 22 butir ketentuan yang menyatakan "diatur dengan undang-undang" atau "diatur lebih lanjut dengan undang-undang”, 11 butir ketentuan yang menyatakan "diatur dalam undang-undang" atau "diatur lebih lanjut dalam undang-undang", dan 6 butir ketentuan menyatakan "ditetapkan dengan undang-undang. Rumusan diatur "dengan" undang-undang yang terdapat dalam ketentuan UUD 1945, diberi makna hal yang diatur dalam ketentuan tersebut harus dirumuskan dalam sebuah undang-undang yang khusus diterbitkan untuk kepentingan itu. Sedangkan rumusan diatur "dalam" undang-undang, diberi makna hal yang diatur dalam ketentuan tersebut dapat menjadi materi muatan suatu atau beberapa undang-undang yang tidak khusus diterbitkan untuk kepentingan itu. Lihat Sekretariat Jenderal MPR RI, Panduan Permasyarakatan Undang-Undang Dasar Negara Republik Indonesia Tahun 1945 dan Ketetapan Majelis Permusyawaratan Rakyat Republik Indonesia, Jakarta, 2012, Hlm. 35 peran yang strategis dalam sistem hukum Indonesia.

Namun demikian, praktek pembentukan undang-undang selama ini kurang responsif, dimana pembentuk undang-undang terkadang kurang memahami perkembangan masyarakat, sehingga banyak undang-undang yang diajukan ke hadapan Mahkamah Konstitusi untuk diuji konstitusionalitasnya, oleh pihak-pihak yang merasa hak konstitusionalnya ${ }^{3}$

3 Jimly Asshiddiqie menyebutkan bahwa yang dikategorikan sebagai hak konstitusional Warga Negara adalah, a) Hak asasi manusia tertentu yang hanya berlaku sebagai hak konstitusional bagi Warga Negara Indonesia saja. Misalnya, hak yang tercantum dalam Pasal 27 ayat (2), Pasal 27 ayat (3), Pasal 28D ayat (3), Pasal 30 ayat (1) dan Pasal 31 ayat (1) UUD 1945, b) Hak asasi manusia tertentu yang meskipun berlaku bagi setiap orang, akan tetapi dalam kasus-kasus tertentu, khusus bagi Warga Negara Indonesia berlaku keutamaan-keutamaan tertentu. Misalnya, hak yang tercantum dalam Pasal 28D ayat (2), Pasal 28E ayat (3) dan Pasal 28H ayat (2) UUD 1945, c) Hak Warga Negara untuk menduduki jabatan-jabatan yang diisi melalui prosedur pemilihan (elected officials), seperti Presiden dan Wakil Presiden, Gubernur dan Wakil Gubernur, Bupati dan Wakil Bupati, Wali Kota dan Wakil Walikota, Kepala Desa, Hakim Konstitusi, Hakim Agung, anggota Badan Pemeriksa Keuangan, anggota Majelis Permusyawaratan Rakyat, anggota Dewan Perwakilan Rakyat, anggota Dewan Perwakilan Daerah, anggota Dewan Perwakilan Rakyat Daerah, Panglima Tentara Nasional Indonesia, Kepala Kepolisian Republik Indonesia, Dewan Gubernur Bank Indonesia, anggota komisi-komisi negara dan jabatan-jabatan lain yang diisi melalui prosedur pemilihan, baik secara langsung atau secara tidak langsung oleh rakyat, d) Hak Warga Negara untuk diangkat dalam jabatan-jabatan tertentu (appointed officials), seperti tentara nasional Indonesia, polisi negara, jaksa, pegawai negeri sipil beserta jabatanjabatan struktural dan fungsional dalam lingkungan kepegawaian dan jabatan-jabatan lain yang diisi melalui pemilihan. e) Hak untuk melakukan upaya hukum dalam melawan atau menggugat keputusan-keputusan negara yang dinilai merugikan hak konstitusional warga negara 
diabaikan oleh berlakunya sebuah undang-undang.

Pasal 5 Ayat (1) Undang-Undang Nomor 48 Tahun 2009 tentang Kekuasaan Kehakiman, menyatakan bahwa Hakim dan hakim konstitusi wajib menggali, mengikuti, dan memahami nilai-nilai hukum dan rasa keadilan yang hidup dalam masyarakat.

Mahkamah Konstitusi ketika melakukan pengujian undang-undang terhadap UUD 1945, dengan sendirinya telah menafsirkan materi muatan UUD 1945 yang menjadi batu uji pengujian undang-undang dimaksud. Secara teoretikal dikenal dua model metode penafsiran undang-undang dasar atau konstitusi, yaitu originalism dan nonoriginalism. Metode originalism, mendasarkan pada intensi pembuat undang-undang dasar dan pengertian murni dari teks undang-undang dasar. Sedangkan metode non-originalism, mendasarkan dan berkaitan dengan pengertian aspirasi yang hidup dan kebutuhan yang berkembang serta relevan. ${ }^{4}$

Terhadap dua metode tersebut, hakim lebih cenderung menggunakan metode originalism, dibandingkan dengan metode non-originalism. Kecenderungan hakim

yang bersangkutan. Lihat Jimly Asshiddiqie, 2007, Pokok-pokok Hukum Tata Negara Indonesia Pasca Reformasi, Bhuana Ilmu Populer, Jakarta, Hlm. 685-686

${ }^{4}$ Albert Hasibuan, Masalah Hubungan Antar Lembaga Tinggi Negara dan Hak Asasi Manusia Berdasarkan UUD 1945. Dalam Bagir Manan (Ed), 1996, Kedaulatan Rakyat, Hak Asasi Manusia, dan Negara Hukum, Kumpulan Esai guna menghormati Sri Soemantri Martosoewignjo, Gaya Media Pratama, Jakarta, Hlm. 100-101. untuk menggunakan metode originalism merupakan hal yang wajar, karena penggunaan metode non-originalism, masih menimbulkan perdebatan di kalangan pengembanan hukum. Namun demikian, dalam praktek peradilan di Mahkamah Konstitusi, hakim Mahkamah Konstitusi pernah melakukan penafsiran konstitusi menggunakan metode nonoriginalism terhadap ketentuan UUD 1945. Hal tersebut diantaranya dapat kita telaah Putusan Nomor 005/PUU-IV/2006, dan Putusan Nomor 138/PUU-VII 2009.

Kegiatan penafsiran merupakan aktivitas yang melekat dengan hukum dan ilmu hukum. Namun, selama ini studi ilmu hukum memberikan tempat yang terbatas terhadap kegiatan penafsiran. ${ }^{5}$

Menurut Bagir Manan, penafsiran merupakan cara (metode) untuk:

1. Memahami makna asas dan kaidah yang terkandung dalam aturan hukum;

2. Mengkaitkan fakta hukum dengan kaidah hukum;

3. Menjamin terlaksananya penerapan dan penegakan hukum secara tepat, benar, dan adil;

4. Mempertemukan kaidah hukum dengan perkembangan sosial, sehingga kaidah hukum dapat menyesuaikan perkembangan dinamika masyarakat. ${ }^{6}$

Berdasarkan uraian tersebut, ilmu hukum sebagai ilmu praktikal yang

5 Jimly Asshiddiqie, 2013, Pengantar Ilmu Hukum Tata Negara, Rajawali Pers, Jakarta, HIm. 249.

${ }^{6}$ Bagir Manan, Beberapa Catatan Tentang Penafsiran, Makalah, Varia Peradilan No. 285 Agustus 2009, Hlm. 5. 
bertugas mempedomani, mengarahkan, dan mengontrol pengembanan hukum praktikal secara rasional, harus mampu menawarkan alternatif penyelesaian permasalahan hukum dimaksud. Maka dari itu, penulis mencoba menguraikan mengenai penafsiran konstitusi dalam lingkup hukum Pancasila.

\section{METODE PENELITIAN}

Penelitian (research) ini merupakan penelitian hukum (legal research). ${ }^{7}$ Berdasarkan jenisnya, termasuk ke dalam penelitian hukum normatif (normative legal research). ${ }^{8}$ Untuk mencapai tujuan

${ }^{7}$ Secara etimologi Penelitian atau research adalah upaya menemukan informasi kembali dengan cermat, hati-hati, tekun, telaten, dan sungguh-sungguh. Makna menemukan adalah kegiatan mencari sesuatu yang sebenarnya telah ada namun belum diformulasikan secara sistematis. Sedangkan secara konseptual penelitian diartikan sebagai suatu rangkaian kegiatan penyelidikan yang meliputi perencanaan, perancangan, manufacturing, pengamatan, analisis dan pengkajian secara sistematik dengan nalar yang logis serta mengikuti kaidah ilmiah, untuk mengungkap rahasia alam atau menyelesaikan suatu permasalahan yang dihadapi manusia demi kesejahteraan umat manusia sendiri. Rangkaian kegiatan dimaksud, harus memfokus pada bidang kajian tertentu. Lihat Ade Saptomo, 2007, Pokokpokok Metodologi Penelitian Hukum, Unesa University Press, Surabaya, Hlm 28.

${ }^{8}$ Menurut Bernard Arief Sidharta, metode penelitian hukum normatif bertumpu pada kaidahkaidah yang mengharuskan, yang kepatuhannya dapat dipaksakan dengan menggunakan alat kekuasaan (normatif), berkiprah dalam dunia keharusan-keharusan (das sollen), dan produknya juga bersifat mengkaidahi. Dunia das sollen itu adalah produk proses dialektikal antara das sein yang berinteraksi dengan dunia das sollen yang produknya diarahkan balik untuk mengatur dunia das sein yang telah memunculkannya. Artinya, dunia tempat berkiprahnya metode normatif ini adalah dunia das sollen-sein. Karena itu, untuk mencapai tujuannya, maka metode normatif itu harus mengakomodasikan cara kerja metode empirik ke dalam kegiatan berkiprahnya. Lihat Bernard Arief Sidharta, Penelitian Hukum penelitian, digunakan metode deskriptif analitis, ${ }^{9}$ sehingga akan diperoleh gambaran umum yang menyeluruh dan sistematis serta keadaan ataupun fakta yang ada tentang penafsiran hukum dalam bingkai hukum Pancasila.

Data yang digunakan dalam penelitian ini bersumber dari bahan hukum primer, bahan hukum sekunder dan bahan hukum tersier, ${ }^{10}$ yang terdiri dari:

a. Bahan Hukum Primer, meliputi Undang-undang Dasar Negara Republik Indonesia Tahun 1945, Undang-Undang Nomor 48 Tahun 2009 tentang Kekuasaan Kehakiman.

b. Bahan Hukum Sekunder, meliputi. hasil-hasil penelitian, teori-teori dan karya tulis dari kalangan sarjana hukum lainnya yang berkaitan dengan permasalahan yang diteliti.

c. Bahan Hukum Tersier, merupakan bahan hukum yang berkaitan dengan bahan hukum primer dan bahan hukum sekunder, seperti Kamus Besar Bahasa Indonesia, Kamus Bahasa Inggris-Indonesia, dan Kamus Hukum. ${ }^{11}$

Normatif: Analisis Penelitian Filosofikal dan Dogmatikal. Dalam Sulistyowati Irianto dan Shidarta (Ed), 2009, Metode Penelitian Hukum: Konstelasi dan Refleksi, Yayasan Obor Indonesia, Jakarta, Hlm. 142-143.

9 Penelitian deskriptif analitis adalah penelitian yang berusaha untuk melukiskan faktafakta dengan bahan-bahan hukum. lihat Soerjono Soekanto dan Sri Marnudji, 1990, Penelitian Hukum Normatif, Rajawali, Jakarta, Hlm 14-15

10 Soerjono Soekanto, 1986, Pengantar Penelitian Hukum, UI Press, Jakarta, Hlm 51-52

${ }^{11}$ Ibid. Hlm. 52 
Bahan-bahan hukum tersebut dikumpulkan melalui studi kepustakaan (library research), ${ }^{12}$ yaitu pengumpulan bahan hukum dari berbagai bahan hukum primer, bahan hukum sekunder dan bahan hukum tersier yang berhubungan dengan topik penelitian. Bahan hukum yang telah diperoleh, dianalisis secara kualitatif, ${ }^{13}$ dengan menggunakan daya abstraksi dan interpretasi dengan merujuk pada kerangka pemikiran serta pandanganpandangan para ahli yang ada relevansinya dengan topik penelitian, yang untuk selanjutnya dideskripsikan dalam bentuk kalimat perkalimat sehingga mudah dipahami dan diinterpretasikan. ${ }^{14}$

\section{HASIL DAN PEMBAHASAN}

Sebagai ilmu praktikal, ilmu hukum bertugas untuk mempedomani, mengarahkan, dan mengontrol pengembanan hukum praktikal secara rasional. Penetapan proposisi hukum (apa kaidah hukumnya) berlandaskan hukum positif yang dipahami (diinterpretasi) berdasarkan makna kata dan struktur kalimatnya (gramatikal), latar belakang sejarah (historikal), tujuannya (teleologikal) serta dalam konteks

12 Studi Kepustakaan merupakan metode tunggal yang dipergunakan dalam penelitian hukum normatif. Lihat Bambang Waluyo, 2008, Penelitian Hukum Dalam Praktek, Sinar Grafika, Jakarta, Hlm. 50

13 Analisis kualitatif digunakan untuk menganalisis makna dari data yang tampak dipermukaan, artinya analisis kualitatif tidak digunakan untuk menjelaskan sebuah fakta tetapi hanya untuk memahami fakta tersebut. Lihat Burhan Bungin (ed), 2006, Metodologi Penelitian Kualitatif, Raja Grafindo Persada, Jakarta, Hlm. 54

${ }^{14}$ Lexy J. Moleong, 2003, Metode Penelitian Kualitatif, Remaja Adikarya, Yogyakarta, Hlm. 45 hubungan dengan aturan-aturan hukum positif yang lainnya (sistematikal), dan secara kontekstual merujuk pada faktorfaktor kenyatan sosial dan ekonomi (sosiologikal) dengan mengacu nilai kultural dan kemanusiaan fundamental (filosofikal) serta prediksi untuk masa yang akan datang (futurologikal). ${ }^{15}$

Berkenaan dengan hal tersebut, serta mewujudkan konstitusi yang hidup, maka penafsiran terhadap kaidah konstitusi harus berdasarkan pada makna kata dan struktur kalimatnya (gramatikal), latar belakang sejarah (historikal), tujuannya (teleologikal) serta dalam konteks hubungan dengan aturan-aturan hukum positif yang lainnya (sistematikal), dan secara kontekstual merujuk pada faktorfaktor kenyatan sosial dan ekonomi (sosiologikal) dengan mengacu nilai kultural dan kemanusiaan fundamental (filosofikal) serta prediksi untuk masa yang akan datang (futurologikal).

Penggunaan metode-metode dimaksud, kemungkinan dapat menyebabkan terjadinya perubahan terhadap makna teks konstitusi. Maka dari itu, ketika pelaksanaan pengujian undangundang, hakim konstitusi dengan sendirinya telah melakukan penafsiran terhadap kaidah-kaidah konstitusi yang menjadi batu ujinya. Untuk meminimalisir jangan sampai terjadinya penyimpangan dalam artian keluar dari

15 Bernard Arief Sidharta, Konsepsi Ilmu Hukum. Dalam Philips A Kana dan Otong Rosadi (penyunting), 2010, 70 Tahun Bintan R Saragih: Percikan Pemikiran Hukum, Ketatanegaraan, dan Kebijakan Publik, Wildan Akademika dan Universitas Ekasakti, Subang-Padang, Hlm. 3 
kebersisteman konstitusi, maka diperlukan batasan ketika melakukan penafsiran terhadap kaidah-kaidah konstitusi.

Pembicaraan tentang batasan penafsiran konstitusi, Bagir Manan menyebutkan sebagai berikut:

"Selain menggunakan berbagai macam metode dan ilmu penafsiran, the living constitution harus dilakukan dalam batasbatas landasan dan cita-cita bernegara. Dalam konteks UUD 1945, penafsiran tidak boleh menyinggung dasar-dasar demokrasi, negara hukum, asas-asas keindonesiaan, dan tujuan bernegara (negara kesejahteraan atas dasar keadilan sosial). Itulah makna the living constitution. Apabila penafsiran UUD 1945 dilakukan diluar dasar-dasar diatas, bukanlah dalam kerangka the living constitution, tetapi meninggalkan UUD $1945 " .16$

Beranjak dari pemikiran yang dikemukakan oleh Bagir Manan tersebut, dapat dikatakan bahwa penggunaan berbagai macam metode penafsiran, perlu diberi pembatasan. Pembatasan yang dimaksud tentu saja dalam lingkup sistem kaidah hukum negara. Sebagai negara yang baru merdeka dan terlepas dari penjajahan dengan tatanan hukum kolonialnya, negara Indonesia telah memilih untuk menyegera mempunyai sistem hukum baru yang berlandaskan pada cara berhukum bangsa Indonesia, ${ }^{17}$

16 Bagir Manan dan Susi Dwi Harijanti, 2015, Memahami Konstitusi: Makna dan Aktualisasi, Rajawali Pers, Jakarta, Hlm. 164.

17 Menurut Mochtar Kusumaatmadja, pada negara-negara yang baru merdeka yang sedang berkembang, terdapat dua faktor yang mendesak yaitu tatanan hukum yang berakar dalam dan bersumber pada nilai-nilai dasar yang digali dari nilai-nilai dan cara baik masyarakat nusantara, yaitu Pancasila. ${ }^{18}$

Mochtar Kusumaatmadja dan B. Arief Sidharta menjelaskan bahwa di dalam Pancasila terdapat prinsip-prinsip hukum umum yang merupakan penggambaran dari tekad dan aspirasi bangsa Indonesia yang mencapai kemerdekaannya dengan perjuangan, yang terdiri dari:

1. Asas ketuhanan mengamanatkan bahwa tidak boleh ada produk hukum nasional yang bertentangan dengan agama atau bersifat menolak atau bermusuhan dengan agama;

2. Asas Perikemanusiaan mengamanatkan bahwa hukum harus melindungi warga Negara dan menjunjung tinggi martabat manusia;

3. Asas persatuan dan kesatuan atau kebangsaan mengamanatkan bahwa hukum Indonesia harus merupakan hukum nasional yang berlaku bagi seluruh bangsa Indonesia. Hukum nasional berfungsi mempersatukan bangsa Indonesia;

4. Asas demokrasi mengamanatkan bahwa dalam hubungan antara hukum dan kekuasaan, kekuasaan harus

diambilnya sikap yang progressip tentang hukum dan peranannya dalam masyarakat, yaitu: 1) keinginan untuk menghapus peninggalan kolonial secepatnya; dan 2) harapan-harapan yang ditimbulkan pada masyarakat dengan tercapainya kemerdekaan. Lihat Mochtar Kusumaatmadja, 1976, Hukum, Masyarakat, Dan Pembinaan Hukum Nasional, Bina Cipta, Bandung, Hlm. 3.

${ }^{18}$ Bernard Arief Sidharta, 2013, Ilmu Hukum Indonesia: Upaya Pengembangan Ilmu Hukum Sistematik Yang Responsif Terhadap Perubahan Masyarakat, Genta Publising, Yogyakarta, Hlm. 96-97 
tunduk pada hukum, bukan sebaliknya. Pada analisis terakhir kekuasaan ada pada rakyat dan wakil-wakilnya;

5. Asas keadilan sosial mengamanatkan bahwa semua warga Negara mempunyai hak yang sama dan bahwa semua orang sama di hadapan hukum. ${ }^{19}$

Kelima asas yang terkandung dalam sila-sila Pancasila, masing-masing mengungkapkan nilai fundamental dan sekaligus juga menjadi lima asas operasional dalam menjalani kehidupan, termasuk dalam penyelenggaraan kegiatan bernegara dan pengembanan hukum (pembentukan, penemuan, dan penerapan hukum). ${ }^{20}$

Senada dengan hal tersebut, Bagir Manan menyebutkan sebagai berikut:

"Pembukaan UUD 1945 menjadi dasar muatan hukum (pembentukan, penerapan, dan penegakan hukum) yang memuat asas-asas hukum (general principles of law) yang berlaku untuk semua bidang hukum. Pembentuk hukum, pelaksana hukum, penegak hukum (terutama hakim) wajib memperhatikan asas-asas hukum umum sebagai sandaran keputusan atau putusan. Mengingat Pancasila mengandung asas-asas hukum umum, maka pembentuk, pelaksana dan penegak hukum, wajib senantiasa memperhatikan isi Pembukaan UUD 1945, bukan sekadar formalitas belaka. Inilah sebenarnya yang diartikan aspek filosofis sebagai salah satu dasar putusan yang adil dalam arti

19 Mochtar Kusumaatmadja dan B. Arief Sidharta, 2000, Pengantar Ilmu Hukum: Suatu Pengenalan Pertama Ruang Lingkup Berlakunya Ilmu Hukum, Alumni, Bandung, Hlm. 138-139. HIm. 98. mampu memberi kepuasan dan menciptakan harmonis sebagai mana dikatakan oleh Leslie Lipson". ${ }^{21}$

Dalam pandangan Bruggink, Pancasila merupakan kaidah penilaian yang fundamental, yang berfungsi sebagai meta-kaidah terhadap kaidah hukum, karena menentukan interpretasi terhadap aturan-aturan hukum dan wilayah penerapan dari aturan-aturan hukum tersebut. Di samping itu, Pancasila juga merupakan pedoman bagi perilaku, walaupun dengan cara yang tidak langsung jika dibandingkan dengan kaidah perilaku. $^{22}$

Menjadikan asas-asas dan kandungan nilai Pancasila sebagai batasan atau sandaran dalam melakukan penafsiran konstitusi merupakan keharusan untuk masa depan Indonesia, sebagaimana yang dicita-citakan dalam Pembukaan UUD $1945 .^{23}$

\section{SIMPULAN}

Berdasarkan pembahasan pada bagian sebelumnya, maka pada bagian ini penulis mencoba menyimpulkan hal-hal sebagai berikut:

21 Bagir Manan dan Susi Dwi Harijanti, 2015, Op. Cit, Hlm. 164.

22 J.J.H. Bruggink, 1999, Refleksi Tentang Hukum, (Alih Bahasa: B. Arief Sidharta), Citra Aditya Bakti, Bandung, Hlm. 119-123

${ }^{23}$ Bandingkan dengan Otong Rosadi, Hukum Kodrat, Pancasila dan Asas Hukum Dalam Pembentukan Hukum di Indonesia, Jurnal Dinamika Hukum, Fakultas Hukum Universitas Jenderal Soedirman, Volume 10 No. 3, September 2010. Lihat juga Jawahir Thontowi, Pancasila Dalam Perspektif Hukum: Pandangan Terhadap Ancaman "The Lost Generation", UII Perss, Yogyakarta, 2016. 
1. Untuk mewujudkan konstitusi yang hidup sehingga responsif terhadap perubahan masyarakat, maka penafsiran terhadap kaidah konstitusi harus berdasarkan pada makna kata dan struktur kalimatnya (gramatikal), latar belakang sejarah (historikal), tujuannya (teleologikal) serta dalam konteks hubungan dengan aturanaturan hukum positif yang lainnya (sistematikal), dan secara kontekstual merujuk pada faktor-faktor kenyataan sosial dan ekonomi (sosiologikal) dengan mengacu nilai kultural dan kemanusiaan fundamental (filosofikal) serta prediksi untuk masa yang akan datang (futurologikal).

2. Asas-asas dan kandungan nilai Pancasila sebagai batasan atau sandaran dalam melakukan penafsiran konstitusi merupakan keharusan untuk masa depan Indonesia, sebagaimana yang dicita-citakan dalam Pembukaan UUD 1945.

\section{DAFTAR PUSTAKA}

\section{Buku-Buku}

Ade Saptomo, 2007, Pokok-pokok Metodologi Penelitian Hukum, Unesa University Press, Jakarta.

Bagir Manan (Ed), 1996, Kedaulatan Rakyat, Hak Asasi Manusia, dan Negara Hukum, Kumpulan Esai guna menghormati Sri Soemantri Martosoewignjo, Gaya Media Pratama, Jakarta.

Bagir Manan dan Susi Dwi Harijanti, 2015, Memahami Konstitusi: Makna dan Aktualisasi, Rajawali Pers, Jakarta.
Bambang Waluyo, 2008, Penelitian Hukum Dalam Praktek, Sinar Grafika, Jakarta.

Bernard Arief Sidharta, 2013, Ilmu Hukum Indonesia: Upaya Pengembangan Ilmu Hukum Sistematik Yang Responsif Terhadap Perubahan Masyarakat, Genta Publising, Yogyakarta.

Burhan Bungin (ed), 2006, Metodologi Penelitian Kualitatif, Raja Grafindo Persada, Jakarta.

J.J.H. Bruggink, 1999, Refleksi Tentang Hukum, (Alih Bahasa: B. Arief Sidharta), Citra Aditya Bakti, Bandung.

Jawahir Thontowi, 2016, Pancasila Dalam Perspektif Hukum: Pandangan Terhadap Ancaman "The Lost Generation", UII Perss, Yogyakarta.

Jimly Asshiddiqie, 2007, Pokok-pokok Hukum Tata Negara Indonesia Pasca Reformasi, Bhuana Ilmu Populer, Jakarta.

Jimly Asshiddiqie, 2013, Pengantar Ilmu Hukum Tata Negara, Rajawali Pers, Jakarta.

Lexy J. Moleong, 2003, Metode Penelitian Kualitatif, Remaja Adikarya, Yogakarta.

Mochtar Kusumaatmadja, 1976, Hukum, Masyarakat, Dan Pembinaan Hukum Nasional, Bina Cipta, Bandung.

Mochtar Kusumaatmadja dan B. Arief Sidharta, 2000, Pengantar Ilmu Hukum: Suatu Pengenalan Pertama Ruang Lingkup Berlakunya Ilmu Hukum, Alumni, Bandung. 
Andi Desmon: Penafsiran Konstitusi Dalam Bingkai Hukum Pancasila

Philips A Kana dan Otong Rosadi (penyunting), 2010, 70 Tahun Bintan $R$ Saragih: Percikan Pemikiran Hukum, Ketatanegaraan, dan Kebijakan Publik, Wildan Akademika dan Universitas Ekasakti, Subang-Padang

Sekretariat Jenderal MPR RI, 2012, Panduan Permasyarakatan Undang-Undang Dasar Negara Republik Indonesia Tahun 1945 dan Ketetapan Majelis Permusyawaratan Rakyat Republik Indonesia, Jakarta.

Soerjono Soekanto, 1986, Pengantar Penelitian Hukum, UI Press, Jakarta.

Soerjono Soekanto dan Sri Marnudji, 1990, Penelitian Hukum Normatif, Rajawali Pers, Jakarta.

Sulistyowati Irianto dan Shidarta (Ed), 2009, Metode Penelitian Hukum: Konstelasi dan Refleksi, Yayasan Obor Indonesia, Jakarta.

\section{Jurnal}

Bagir Manan, Beberapa Catatan Tentang Penafsiran, Makalah, Varia Peradilan Nomor 285 Agustus 2009.
Darda Pasmatuti, Analisa Terhadap Putusan Mahkamah Kontitusi Nomor 46/Puu-Viii/2010 Mengenai Status Anak, Volume 3, Nomor. 1, September 2017.

Otong Rosadi, Hukum Kodrat, Pancasila dan Asas Hukum dalam Pembentukan Hukum di Indonesia, Jurnal Dinamika Hukum, Fakultas Hukum Universitas Jenderal Soedirman, Volume 10 Nomor 3, September 2010.

\section{Peraturan Perundang-Undangan}

Undang-Undang Dasar Negara Republik Indonesia Tahun 1945.

Undang-Undang Nomor 48 Tahun 2009 tentang Kekuasaan Kehakiman.

\section{Putusan Mahkamah Konstitusi}

Putusan Nomor 005/PUU-IV/2006.

Putusan Nomor 138/PUU-VII 2009. 